\title{
Examining Curriculum Efficiency from Learners' Perspective: A Case Study of Translation Criticism Course of Iranian Universities
}

\author{
Reza Rezvani (Corresponding author) \\ School of Humanities, Yasouj University, Yasouj, Iran \\ E-mail: rezvanireza@gmail.com \\ Mina Vakilinejad \\ Department of Foreign Languages \& Linguistics, Payame Noor University, Ahvaz branch \\ Pardis, Ahvaz, Khouzestan, Iran \\ E-mail: mina_vakilinejad@yahoo.com
}

Received: 04-07-2014

Accepted: 04-09-2014

Published: 01-01-2015

doi:10.7575/aiac.ijalel.v.4n.1p.151

URL: http://dx.doi.org/10.7575/aiac.ijalel.v.4n.1p.151

\begin{abstract}
Although students are regarded as the key party of interest in education, they are rarely asked to contribute to identifying and organizing what and how they should learn. This article attempted to explore the efficiency of translation criticism course as one of the key courses offered in Translation Studies around the world at M.A. level from students' perspective. A use was made of a questionnaire developed by the current researchers in order to gather data. Sixty one M.A. students from four Iranian universities who took the course participated in this survey. Qualitative analysis of the data revealed the students' dissatisfaction with the current curriculum and its implementation. The findings also pointed to the need for restructuring the curriculum and its delivery, together with the necessity of taking into consideration the students' learning needs in the process of curriculum and syllabus design. Some recommendations for improving the pedagogical quality of the course will also be suggested.
\end{abstract}

Keywords: translation criticism, course syllabus, official curriculum, needs analysis

\section{Introduction}

Performance assessment "is a method of educational evaluation based on the measurement of an individual's proficiency at executing various complex tasks" (Jones, 2010, p. 635). After the establishment of Translation Studies (TS) as an academic discipline, so many performance assessment research and studies were conducted in order to find errors and defects of the students and graduates of TS and to suggest some solutions to correct these errors. Such inquiries examine translator and translation students' performance pieces painstakingly in search of actual defects neglecting the larger-scale and higher-order factors in translator education which may have given rise to such defective performance. In other words we tend to argue that while assessment of students' and translators' performance reveals their mistakes and errors in performing their tasks, it does not necessarily provide enough information about their sources and causes. A careful and systematic evaluation of the course and official curriculum can provide valuable information about the deficiencies of the TS education and training. Evaluative studies provide valuable information to help curriculum developers and administrators make informed decisions to remedy weaknesses of curriculum and to improve education quality. In a similar vein, Rezvani, Farahzad, and Vakilinejad (2012) point out "in Translation Studies, evaluation has focused, for the most part, on the student performance and determining how this performance can be enhanced. However, there have been few studies... addressing the curriculum evaluation of university courses of English program" (p. 84).

Evaluation in educational settings can be defined as the process of collection and analyzing obtained information about teaching and learning in order to make informed decisions that enhance learners' achievement and the success of educational programs (Brown, 1995; Genesee \& Upshur, 1996; Rea-Dickins \& Germaine, 1993). Evaluation "is essential to successful education because it forms the basis for appropriate and effective decision-making" (Genesee, 2002 , p. 150). Evaluation, in any form -monitoring or feedback- should also be regarded as a vital component of research in education, since quality control is an important element of any educational system. "It is through monitoring and feedback that planned and actual outcomes can be compared and appropriate remedial action taken to repair failures or defects" (White, 1988, p. 5).

The importance of curriculum and course evaluation has been attested in a few studies addressing the limitations and drawbacks of the translation courses and curriculum. An example of such evaluative studies was carried out by Rezvani et al. (2012). In their study, they examined the effectiveness of the official curriculum of Translation Quality Assessment (TQA) course at M.A. level from the viewpoint of the students. Noting that the assessment of translation 
quality is neglected in the program, they made some suggestions to make up for the deficiencies identified. In another evaluative study conducted by Rezvani and Vakilinejad (2014) appropriateness of official curriculum of TQA course was examined from instructors' standpoints.

In this study the focus centers on the efficiency of the official curriculum of Translation Criticism (TC) course which is one of the core courses of TS at M.A. level and one of the most important and crucial issues in TS. The official curriculum of this course approved by the Ministry of Science, Research, and Technology of Iran offered the following objectives for this 2-unit one-semester course:

- to read, discuss, analyze and critique examples of scientific and literary masterpieces with emphasis on their scientific, social and educational contents;

- to analyze translation comparatively with focus on word meaning, correct equivalent of idioms and expressions, descriptive, explanative and argumentative clauses, success or failure of the translator in delivering tone and style of the source text as well as strategies s/he adopted when faced with untranslatable items; and,

- in the case of scientific and technical texts, to divide the class into several groups and for each group to choose a particular field of science and to examine the translation of selected texts in that field through comparative analysis and discussion.

In this article, we look in detail at the official curriculum of Translation Criticism course which is one of the most important and fundamental courses of Translation Studies at M.A. level. The main objective of this research was to explore the students' opinions and judgments about the TC curriculum and course syllabi employing a qualitative questionnaire. The present paper looks especially at the students' learning needs to see whether or not the current curriculum and teaching methodologies adopted by the instructors align with their needs.

\section{Literature review}

There is a sizable body of literature on the subject of curriculum and program evaluation. Most of the proposed models and frameworks can be classified according to their purpose or their method of analysis. As Brown (1995) pointed out different approaches that have been proposed in the literature of program evaluation can be placed into one of four categories. Product-oriented approaches focus on instructional goals and objectives to determine whether they have been achieved. Static-characteristic approaches involve studies, which are conducted to determine program effectiveness. Process-oriented approaches were emerged partially "due to the realization that meeting program goals and objectives, while important, was not very helpful in facilitating curriculum revision, change, and improvement" (Brown, 1995, p. 222). Decision-facilitation approaches derive from the belief that the most important function of education is to help in decision making.

Stufflebeam (2002) distinguished between 22 program evaluation approaches and grouped all of them into four kinds: Pseudoevaluations are studies that "masquerade as valid evaluations, but conceal, distort, or falsify the evaluation findings" (Love, 2010, p. 804). The motivation behind pseudoevaluations is often political objectives. Question/methods-oriented approaches "(1) address specified questions, answers to which may or may not be sufficient to assess a program's merit and worth and/or (2) use some preferred method(s)" (Stufflebeam, 2002, p. 40). Improvement/accountability-oriented approaches evaluate a program's merit and worth. "These evaluations also foster program improvement by supplying information about program options and competing programs" (Love, 2010, p. 805). Social agenda/advocacy-directed approaches try to make a difference in society through program evaluation. "These approaches seek to ensure that all segments of society have equal access to educational and social opportunities and services" (Stufflebeam, 2002, p. 68).

According to Klenowski (2010, p. 335), curriculum evaluation involves determining the values or worth of particular products or processes that can include learning objectives, documents, or experiences for the purposes of informing decision making about the curriculum. Chelimsky (1997) identified three purposes for curriculum evaluation: accountability (measurement of results or efficiency), development (to develop or improve), and knowledge (deeper understanding of practice or policy).

Levin (2010) noted that "various approaches to curriculum evaluation can be grouped into three different orientations based on the epistemological views, educational and methodological beliefs, and axiological perspectives that they espouse" (p. 637). These three orientations are characterized as follows: (1) instrumental evaluation; (2) adaptive and situated evaluation; and (3) emergent and emancipator evaluation. Instrumental curriculum evaluation is a technicalrational approach because "it regards curriculum decisions or actions as standardized, systematic, and objectively reached mainly by evaluation experts, based on a means-ends rationale" (Ibid). This approach is productive since it sees curriculum evaluation as a process with the main purpose of rendering unequivocal judgment (Levin, 2010). "It is disseminative in that it regards evaluation as a top-down model of search for a proven model of a quality curriculum to be generalized and assimilated everywhere" (Ibid. p. 637). Instrumental curriculum evaluation has three basic characteristics:

(1) the evaluators' input is limited to technical decision making; (2) the impact on the curriculum is limited leading to little or no understanding of the specific circumstances of the evaluation; and (3) there is a monologic relationship between curriculum developers, users, and evaluators, where the set of evaluation standards authoritatively dictates expectations of a quality curriculum (Ibid, p. 638).

The main rules guiding this kind of evaluation are standards and the search for the best practices (Levin, 2010). 
Situated and adaptive evaluation orientation "conceives curriculum evaluation as an adaptive, productive knowledge construction process driven by in-school, situated, specific considerations and needs but directed and conditioned by mandated and prescribed evaluation policy" (Ibid, p. 638). Based on this orientation, curriculum evaluation occurs within the context of a school with teachers and students and considers their needs and expectations while framed and controlled by a central authority (Levin, 2010). Three characteristics of this evaluation orientation are as follows:

(1) the evaluation experience involves questioning curricular goals and processes with a view to improving the curriculum, its relevancy, and its accomplishments for specific circumstances; (2) the evaluation process is deliberative and aims to achieve knowledge growth by responding to local perspectives and needs, theoretical considerations, and mandated guidelines; and (3) the relationship is dialogic: evaluators, authority representatives, and local stakeholders, mainly teachers, enter into dialogue aimed at understanding and influencing the evaluation processes, and arriving to a consensus concerning dimensions of curriculum quality. (Ibid.)

Emergent and emancipator evaluation orientation "entails a continuous knowledge co-construction, dialogicalnegotiated, and authentic experience regarding meanings, actions, and values" (Ibid, p. 639). It is a reflective meaningmaking process which is situated and interwoven with curriculum evolution and contributes to ongoing learning (Levin, 2010).

Despite the importance and significance of curriculum research, there is a paucity of curriculum evaluation research in TS. Thus, as Rezvani and Vakilinejad (2014) stated, "there is a need for empirical research studies on curricular effectiveness" of TS curriculum.

\section{Method}

\subsection{Instrumentation}

The main instrument used in this research was a qualitative questionnaire developed by the current researchers. It was developed based on the theoretical and empirical literature on curriculum evaluation. Its content validity was examined and established through consultation with three experts (Ph.D.) in translation studies. The original questionnaire was piloted with 31 TS M.A. students with similar characteristics to the targeted sample and necessary amendments were made according to the feedback provided by both the experts and students about the clarity and relevance of the items. The final questionnaire comprised three independent sections with items on students' attitudes toward the official curriculum, their perceptions of the syllabus and their knowledge after the course implementation. A four-item Likert scale was utilized for all the questions. After two phases of the survey, the frequencies and percentages for each item were calculated and reported.

\subsection{Participants}

Sixty seven M.A. students from four Iranian universities who took the course of Translation Criticism participated in this survey. Six students' incomplete questionnaires were excluded from the data analysis. The final sample included 22 male and 39 female students.

\subsection{Data collection and analysis}

Data collection for this research was completed during the academic year of 2012-2013. This survey was conducted in two phases. The questionnaire was first administered to 61 M.A. students from four universities of Iran. In the second phase of the study, the questionnaire was re-administered to the same group at the end of the semester. The collected data were analyzed qualitatively to determine whether or not the official curriculum was successful to make students familiar with concepts and principles of translation criticism and to enhance their translation criticism skills.

\section{Results}

The questionnaire used in this survey comprised three independent sections on the official curriculum of the course, the syllabus of the course, and students' knowledge change. The following parts present summaries of the major themes emerging from the questionnaire data analysis.

\subsection{Official curriculum}

This section of the questionnaire elicited the students' ratings of various aspects of the official curriculum such as course objectives and class activities suggested. The first question of this section was about the extent to which the students were familiar with the official curriculum. Contrary to our expectation a very small number of students $(6 \%)$ were familiar with the curriculum completely (see Table 1). We hoped that at the end of the semester the students would be acquainted with the curriculum but as it is shown in Table 1 in the second phase of the study a majority of them were "very little" (33\%) familiar with the curriculum and only $29 \%$ of the students were familiar with it "to some extent". This might be indicative of one of the main deficiencies and drawbacks of the course that is discussed in greater detail in subsequent sections. 
Table 1. Students' views about the official curriculum

\begin{tabular}{|c|c|c|c|c|c|c|c|c|c|}
\hline & & \multicolumn{2}{|c|}{ Not at all } & \multicolumn{2}{|c|}{ Very little } & \multicolumn{2}{|c|}{$\begin{array}{l}\text { To some } \\
\text { extent }\end{array}$} & \multicolumn{2}{|c|}{ completely } \\
\hline & & Fr. & Per. & Fr. & Per. & Fr. & Per. & Fr. & Per. \\
\hline \multirow[t]{2}{*}{ Familiarity with the official curriculum } & Phase 1 & 31 & 51 & 17 & 28 & 9 & 15 & 4 & 6 \\
\hline & Phase 2 & 6 & 10 & 20 & 33 & 18 & 29 & 17 & 28 \\
\hline \multirow[t]{2}{*}{ Clarity of the course objectives } & Phase 1 & 1 & 25 & 3 & 75 & & & & \\
\hline & Phase 2 & 4 & 24 & 1 & 6 & 7 & 41 & 5 & 29 \\
\hline \multirow{2}{*}{$\begin{array}{l}\text { Attainability of the course objectives } \\
\text { through one semester }\end{array}$} & Phase 1 & 2 & 50 & 1 & 25 & 1 & 25 & & \\
\hline & Phase 2 & 1 & 6 & 9 & 53 & 5 & 29 & 2 & 12 \\
\hline \multirow{2}{*}{$\begin{array}{l}\text { Relevance of the course objectives to } \\
\text { students' needs }\end{array}$} & Phase 1 & 1 & 25 & & & 2 & 50 & 1 & 25 \\
\hline & Phase 2 & 1 & 6 & 1 & 6 & 5 & 29 & 10 & 59 \\
\hline \multirow{2}{*}{$\begin{array}{l}\text { Appropriateness of the curriculum for } \\
\text { the improvement of students' } \\
\text { knowledge of TC }\end{array}$} & Phase 1 & & & & & 3 & 75 & 1 & 25 \\
\hline & Phase 2 & 1 & 6 & 5 & 29 & 9 & 53 & 2 & 12 \\
\hline \multirow{2}{*}{$\begin{array}{l}\text { Appropriateness of the curriculum for } \\
\text { students' preliminary knowledge of TC }\end{array}$} & Phase 1 & & & & & 4 & 100 & & \\
\hline & Phase 2 & 9 & 53 & 4 & 23 & 3 & 18 & 1 & 6 \\
\hline \multirow{2}{*}{$\begin{array}{l}\text { The extent to which the syllabus } \\
\text { follows the curriculum }\end{array}$} & Phase 1 & & & & & 1 & 25 & 3 & 75 \\
\hline & Phase 2 & & & 2 & 12 & 5 & 29 & 10 & 59 \\
\hline \multirow{2}{*}{$\begin{array}{l}\text { Inclusion of enough class work in the } \\
\text { curriculum }\end{array}$} & Phase 1 & & & & & 4 & 100 & & \\
\hline & Phase 2 & & & 1 & 6 & 4 & 23 & 12 & 71 \\
\hline \multirow{2}{*}{$\begin{array}{l}\text { The extent to which The curriculum } \\
\text { enables students to participate in class } \\
\text { actively }\end{array}$} & Phase 1 & & & & & 2 & 50 & 2 & 50 \\
\hline & Phase 2 & 1 & 6 & 1 & 6 & 6 & 35 & 9 & 53 \\
\hline \multirow{2}{*}{$\begin{array}{l}\text { Positive effect of proposed class work } \\
\text { on learning }\end{array}$} & Phase 1 & & & & & 3 & 75 & 1 & 25 \\
\hline & Phase 2 & & & 3 & 18 & 8 & 47 & 6 & 35 \\
\hline
\end{tabular}

The students who were familiar with the official curriculum completely were asked to answer the remaining questions of this section. So, from among 61 participants only 4 students $(6 \%)$ in the first phase and 17 of them $(27 \%)$ in the second phase responded to those questions.

As it was revealed by Table 1, before the implementation of the curriculum a large number of respondents $(75 \%)$ stated that the course objectives were clear to them "very little'. Half of the students thought that it is impossible to attain the course objectives through one semester. At the same time, the same percentage of the participants considered the course objectives "to some extent" relevant to their needs. A majority of the respondents $(75 \%)$ believed that the curriculum was "to some extent" appropriate for the improvement of the students' knowledge of TC. And all of the students were of the opinion that the curriculum was "to some extent" appropriate for the students' preliminary knowledge. The next questions were about class activities of the curriculum and their effects on the students' learning. In the first phase of the study, participants appeared to hold a neutral attitude towards the class activities proposed by the curriculum as evidenced by the fact that all of them indicated that the suggested activities were enough "to some extent" and a high percentage of them (75\%) thought that the activities were effective in learning "to some extent".

In the second phase of the survey, $41 \%$ of the respondents stated that the course objectives were clear to them "to some extent". About half of the participants (53\%) declared that the probability of the attainability of the course objectives through one semester was "very little". A majority of the respondents (59\%) admitted that course objectives were relevant to the students' needs "completely". Although 53\% of the students rated the appropriateness of the curriculum to improve the students' knowledge of TC "to some extent", the same number of them thought that the curriculum was not appropriate for the students' preliminary knowledge of TC at all. Most of the students (59\%) also stated that the syllabus followed the curriculum "completely". After the curriculum implementation, a large number of the participants $(93 \%)$ held a relatively positive view toward class activities of the curriculum. As it can be seen in Table 1, a high percentage of them $(71 \%)$ believed that the curriculum included enough class activities. In addition, around half of them $(47 \%)$ indicated that the activities had some effects on their learning and some respondents (35\%) maintained that they were effective completely.

\subsection{Course syllabus}

In this section of the questionnaire, the whole sample $(n=61)$ were asked to answer some questions about the course syllabus proposed by their instructor. The following table summarizes the answers. 


\begin{tabular}{|c|c|c|c|c|c|c|c|c|c|}
\hline & & \multicolumn{2}{|c|}{ Not at all } & \multicolumn{2}{|c|}{ Very little } & \multicolumn{2}{|c|}{$\begin{array}{c}\text { To some } \\
\text { extent }\end{array}$} & \multicolumn{2}{|c|}{ Completely } \\
\hline & & Fr. & Per. & Fr. & Per. & Fr. & Per. & Fr. & Per. \\
\hline \multirow{2}{*}{$\begin{array}{l}\text { The extent to which the syllabus } \\
\text { supports course objectives }\end{array}$} & Phase 1 & 5 & 8 & 18 & 30 & 31 & 51 & 7 & 11 \\
\hline & Phase 2 & 7 & 11 & 12 & 20 & 27 & 44 & 15 & 25 \\
\hline \multirow{2}{*}{$\begin{array}{l}\text { Appropriateness of syllabus for } \\
\text { students' level }\end{array}$} & Phase 1 & 3 & 5 & 19 & 31 & 31 & 51 & 8 & 13 \\
\hline & Phase 2 & 14 & 23 & 28 & 46 & 7 & 11 & 12 & 20 \\
\hline \multirow{2}{*}{$\begin{array}{l}\text { Appropriateness of syllabus for the } \\
\text { improvement of students' knowledge } \\
\text { of TC }\end{array}$} & Phase 1 & 7 & 12 & 13 & 21 & 23 & 38 & 18 & 29 \\
\hline & Phase 2 & 5 & 8 & 17 & 28 & 26 & 43 & 13 & 21 \\
\hline \multirow{2}{*}{$\begin{array}{l}\text { Success of syllabus in introducing } \\
\text { principles of criticism }\end{array}$} & Phase 1 & 7 & 12 & 21 & 34 & 25 & 41 & 8 & 13 \\
\hline & Phase 2 & 8 & 13 & 17 & 28 & 26 & 43 & 10 & 16 \\
\hline \multirow{2}{*}{$\begin{array}{l}\text { Success of syllabus in introducing } \\
\text { principles of TC }\end{array}$} & Phase 1 & 8 & 13 & 19 & 31 & 13 & 21 & 21 & 35 \\
\hline & Phase 2 & 16 & 26 & 31 & 51 & 9 & 15 & 5 & 8 \\
\hline \multirow{2}{*}{$\begin{array}{l}\text { Inclusion of enough practice of } \\
\text { criticism }\end{array}$} & Phase 1 & 3 & 5 & 23 & 38 & 29 & 47 & 6 & 10 \\
\hline & Phase 2 & 2 & 3 & 9 & 15 & 18 & 30 & 32 & 52 \\
\hline \multirow[t]{2}{*}{ Inclusion of enough practice of TC } & Phase 1 & 7 & 11 & 12 & 20 & 29 & 48 & 13 & 21 \\
\hline & Phase 2 & 4 & 6 & 7 & 12 & 23 & 38 & 27 & 44 \\
\hline \multirow[t]{2}{*}{ Inclusion of enough class work } & Phase 1 & 8 & 13 & 5 & 8 & 18 & 30 & 30 & 49 \\
\hline & Phase 2 & & & 8 & 13 & 20 & 33 & 33 & 54 \\
\hline \multirow{2}{*}{$\begin{array}{l}\text { Positive effect of class work on } \\
\text { students learning }\end{array}$} & Phase 1 & 6 & 10 & 14 & 23 & 31 & 51 & 10 & 16 \\
\hline & Phase 2 & 6 & 10 & 15 & 25 & 26 & 42 & 14 & 23 \\
\hline \multirow[t]{2}{*}{ Balance between theory and practice } & Phase 1 & 4 & 7 & 24 & 39 & 21 & 34 & 12 & 20 \\
\hline & Phase 2 & 15 & 25 & 29 & 47 & 12 & 20 & 5 & 8 \\
\hline
\end{tabular}

The first question of this section addressed the extent to which the syllabus supported the course objectives. What is evident is that the answers of the two phases varied relatively. As regards the appropriateness of the syllabus for the students' levels, half of the students $(51 \%)$ thought it matched their level "to some extent" in the first phase. This index decreased to $11 \%$ in the second phase and $46 \%$ of the respondents believed that it was appropriate very little. In both phases, the participants held a neutral view toward the appropriateness of the syllabus to improve the students' knowledge of TC.

With respect to the success of syllabus in introducing the principles of criticism, the results of both phases were closely similar. Before the curriculum implementation, the respondents held different views on it. What is surprising is that there was a consensus on the inefficiency of the syllabus in achieving this crucial objective at the end of the semester.

Some items of the questionnaire were about the practice and class activity of the course syllabus. A majority of the participants were generally satisfied with the extent TC practice the students were supposed to undertake. Further, their answers to the item about the amount of class activity assigned by the syllabus were consistent with the results of the two previous questions. When we asked the respondents about the positive effect of class activities on their learning, in both phases a high percentage of them declared that the activities were either "to some extent" (51\% in the first and $42 \%$ in the second phase) or "very little" (23\% and $25 \%$ in the first and second phase, respectively) effective.

Table 3. Students' views on the effectiveness of TC theory and practice

\begin{tabular}{lcccccc}
\hline $\begin{array}{l}\text { The most effective } \\
\text { factor }\end{array}$ & \multicolumn{3}{c}{ Theory } & \multicolumn{2}{c}{ Practice } & \multicolumn{2}{c}{$\begin{array}{c}\text { Balance between theory and } \\
\text { practice }\end{array}$} \\
\cline { 2 - 7 } & Fr. & Per. & Fr. & Per. & Fr. & Per. \\
\hline Phase 1 & 9 & 15 & 16 & 26 & 36 & 59 \\
\hline Phase 2 & 5 & 8 & 16 & 26 & 40 & 66 \\
\hline
\end{tabular}

One of the significant areas of concern for the current researchers was the integration between theory and practice in TC classrooms. There was no significant difference between the results of the first and second phases of the study. As Table 3 shows, striking a balance and integration between theory and practice was deemed to be an effective factor contributing to the TC course to accomplish the targeted course goals. However, it seems that it was neglected by the course instructors (see Table 3).

\subsection{Students' knowledge attainment}

This part specifically seeks to identify what students learned about TC. A comparison of data obtained from the first and second phases of the study indicates the extent to which the curriculum of this course was successful in achieving its objectives. The results of this section are presented in Table 4. 
Table 4. Students' knowledge of criticism and TC

\begin{tabular}{lcccccccccc}
\hline Students' knowledge of & & \multicolumn{2}{c}{ Not at all } & \multicolumn{2}{c}{ Very little } & \multicolumn{2}{c}{ To some extent } & \multicolumn{2}{c}{ Completely } & Total \\
\cline { 2 - 12 } & & Fr. & Per. & Fr. & Per. & Fr. & Per. & Fr. & Per. \\
\hline General concepts of TC & Phase 1 & 19 & 31 & 28 & 46 & 11 & 18 & 3 & 5 & 61 \\
\cline { 2 - 12 } & Phase 2 & 3 & 5 & 16 & 26 & 22 & 36 & 20 & 33 & 61 \\
\hline Theories of TC & Phase 1 & 33 & 54 & 19 & 31 & 8 & 13 & 1 & 2 & 61 \\
\cline { 2 - 11 } & Phase 2 & 8 & 13 & 29 & 48 & 13 & 21 & 11 & 18 & 61 \\
\hline
\end{tabular}

As it can be seen in Table 4, in the first phase of the study, $18 \%$ and $5 \%$ of the students were familiar with the general concepts of TC "to some extent' and "completely", respectively. These indexes expectedly rose to $36 \%$ and $33 \%$ respectively in the second phase. With respect to theories of TC $13 \%$ and $2 \%$ of the participants were familiar with the targeted aim "to some extent" and "completely" at the beginning of the course, respectively. In the second phase, these numbers grew to $21 \%$ and $18 \%$ respectively. In sum, these data generally indicate that this course was not much successful in making the students familiar with TC general principles and theories.

In the second phase of the study, an open-ended question was also added to the questionnaire and asked the students to comment on the course. The content analysis of the responses, lead additionally to some significant themes congruent with the findings reviewed above. One important theme, or better complaint frequently expressed, among others, was that they were forced to critique several texts without first grasping the theoretical knowledge about the principles and theories of TC. In other words, they were urged to critique translations without theoretically knowing how to critique. Further, they stated that the instructors generally focused on only the criticism of literary texts and other genres were neglected.

\section{Discussion}

The findings of this research offer some guidelines for the amendment and improvement of the official curriculum of TC course. In particular, the findings outlined here specify the aspects of the curriculum, which are actually inappropriate and problematic. Our discussion brings forth important points in relation to the course objectives, the inappropriacy of the curriculum for the students' level, the necessity of conducting course and curriculum evaluation, and the balance between TC theory and practice.

One of the crucial issues in the early stages of the course and curriculum development is to identify the needs of the learners through needs analysis. Needs analysis is a procedure to collect required information to determine students' needs. Such information may prove necessary to design a program or curriculum, and it is essential to get a general notion of what should be set as course objectives and what should be included in course content. Curriculum designers together with the instructors ought to take into consideration such learners' needs accounts. This enables the curriculum designers and instructors to define more informed and appropriate course objectives and as Knox (2002) pointed out to be more responsive to the potential learners. Brown maintains that:

checking at the beginning of the curriculum development process to see if program objectives are set at the appropriate level for the students is far more productive than waiting until after the program is firmly in place, at which point costly materials, equipment, and staff decisions have already been made. (1995, p. 110)

In the light of the finding that most students were not satisfied with the current curriculum and syllabuses and that they held a negative attitude toward them as they thought that they could not meet their needs and expectations, it seems that the present curriculum requires modification. This finding is supported by the result of a similar study by Rezvani et al. (2012) in which they noted the need to revise and restructure the official M.A. curriculum of Translation Quality Assessment. The results were also in line with another evaluation study in Iranian higher education ESP context. Mal Amiri (2008) conducted a program evaluation research and examined ESP education at MS/A and Ph.D levels in Islamic Azad University in Iran. Similarly, she came to the conclusion that the students' learning needs were not taken into account in the process of curriculum and program development and therefore, they were not satisfied with the curriculum. Thus, it is recommended that the curriculum be modified in line with the students' learning needs. In particular, it is suggested that the course provide the students with preliminary knowledge and principles of TC before requiring them to critique translation products through hands-on activities. The course instructors should not wait for the top-down modifications and they ought to initiate the changes themselves. As suggested by Rezvani et al. (2012), they are the agents of instruction and change who are closely in touch with the learners and informed by their ongoing first-hand information. Taking into account the formative feedback they obtain on the curriculum and their own syllabi they can actively respond to the learners expectations and needs through tailoring "logically the difficulty of the course materials, topics coverage, course delivery format etc.” (Rezvani, et al., 2012, p. 95).

Curriculum evaluation as a research topic is of considerable potential and importance in translator education, but unfortunately it seems that it is often overlooked by those who examine students' knowledge and performance. Bachman (1990, p. 23) asserts that "it is only when the results of tests are used as a basis for making a decision that evaluation is involved". "Evaluation can involve looking at every aspect of a course to judge if the course is adequate and whether it needs improvement. It is generally a neglected aspect of curriculum design" (Nation \& Macalister, 2010, p. 2). To evaluate translators' performance effectively, it is important to analyze the education and training they 
experienced, that is, what they were taught and how they were taught. This plays up the significance of curriculum and course evaluation as a theme of research in the field of translator education.

Instructional objectives can be defined as "specific statements that describe the particular knowledge, behavior, and/or skills that the learner will be expected to know or perform at the end of a course or program" (Brown, 1995, p. 73). The point that a fairly high percentage of the study respondents had either no or little familiarity with the all-important course objectives even at the end of the course might be regarded as a fundamental deficiency of the course. A similar finding was reported in Atai and Nazari's (2011) evaluative study in Iranian higher education context. They found that a high percentage of students of an EAP course in Iranian Universities were not fully aware of the aims courses. It is suggested that the students be made fully aware of what the course objectives are and how they are going to be accomplished. This awareness leads to more logical expectations and better preparation. Further, such understanding encourages students to concentrate on long-term objectives intended by the course rather than on the more immediate ones which help them just pass the course when they do not know what they are actually learning (Rezvani et al., 2012).

The official curriculum standard of the course, as touched upon in the introduction to this paper, indicates that the course favors TC practice and it is largely activity-oriented. It was also revealed in the participants' responses and comments. This emphasis on TC practice both in the standard and accordingly in the instructors' instruction lead to an unproductive imbalance between theory and practice of TC. The students were required to critique without first acquiring the theoretical foundation of TC and knowing how to do so. This was evidenced by the data. It might be reasoned that the stipulations of the curriculum standards made or induced the course instructors to orient the course focus and course work to TC practice to a larger extent. This was supported and argued by Rezvani (2013) in a closely comparable evaluative study of the official curriculum the same course. Rezvani (2013), examining it from the Iranian course instructors' perspectives, reported that they were not satisfied with the current course curriculum and that they held that a majority of their students did not have the required preliminary knowledge for the course. Concurring with Fink (2003), we tend to argue that the students should be first provided with the requisite theoretical knowledge and content and then be expected to apply what they have mastered. More specifically, it may be suggested to offer a prerequisite course or dedicate half of the same course to theoretical issues and guidelines before immersing the students in the practical TC tasks. In this regard, appropriate materials play a key role in helping both teachers and students (Richards, 1993). What complicates the issue and raises a grave problem is that there appears to be a paucity of materials on theoretical issues of TC. This problem acutely engages the instructors' provision and improvisation.

\section{Conclusion}

Translation Criticism is one of the main and controversial topics in the field of TS and one of the key courses offered in Translation Studies at M.A. level in universities. The present paper looks specifically at learning needs of the students who took this course to see whether or not the current curriculum of this course and teaching methodologies adopted by the course instructors correspond with them. In this study, we employed a qualitative questionnaire to examine the students' opinions and judgments about the official curriculum and course syllabus and to explore the course efficiency from the students' perspective.

In general, the results of the study indicates that there was an imbalance between TC theory and practice. The course almost exclusively favored the latter resulting in the students' confusion regarding how to critique translation. Thus, it is suggested that the current curriculum be modified in order to accommodate the students' needs and expectations to a larger extent.

This paper also documents the course and curriculum evaluation as an opportunity for identifying the deficiencies in translator education. We suggest that needs assessment be undertaken before designing a curriculum and that a curriculum and its components be on-goingly evaluated to align teaching with learning in general.

\section{References}

Atai, M. R., \& Nazari, O. (2011). Exploring reading comprehension needs of Iranian EAP students of health information management (HIM): A triangulated approach. System, 39, 30-43.

Bachman, L. F. (1990). Fundamental considerations in language testing. Oxford: Oxford University Press.

Brown, J. D. (1995). The Elements of language curriculum: A Systematic approach to program development. Boston: Heinle \& Heinle Publishers.

Chelimsky, E. (1997). Thoughts for a new evaluation society. Evaluation, 3, 97-118.

Fink, L. D. (2003). Creating significant learning experiences: An integrated approach to designing college courses. San Francisco, CA.: Jossey-Bass.

Genesee, F. (2002). Evaluation. In R. Carter \& D. Nunan (Eds.), The Cambridge guide to teaching English to speakers of other languages ( $4^{\text {th }}$ ed., pp. 144-150). Cambridge: Cambridge University Press.

Genesee, F. \& Upshur. J. (1996). Classroom-Based Evaluation in Second Language Education. Cambridge: Cambridge University Press.

Jones, T. O'C. (2010). Performance assessment. In C. Kridel (Ed.), Encyclopedia of curriculum studies (pp. 635-637). California: SAGE Publications. 
Klenowski, V. (2010). Curriculum evaluation: Approaches and methodologies. In P. Peterson, E. Baker, \& B. McGraw (Eds.), International encyclopedia of education ( $3^{\text {rd }}$ ed., Vol. 1, pp. 335-341). Oxford: Elsevier Ltd.

Knox, A. B. (2002). Evaluation for Continuing Education: A Comprehensive Guide to Success. San Francisco: JOSSEY-BASS.

Levin, T. (2010). Curriculum evaluation. In P. Peterson, E. Baker, \& B. McGraw (Eds.), International encyclopedia of education ( $3^{\text {rd }}$ ed., Vol. 3, pp. 636-644). Oxford: Elsevier Ltd.

Love, A. J. (2010). Understanding approaches to evaluation. In P. Peterson, E. Baker \& B. McGaw (Eds.), International encyclopedia of education ( ${ }^{\text {rd }}$ ed., Vol. 3, pp. 798- 807). Oxford: Elsevier Ltd.

Mal Amiri, B. (2008). A program evaluation of ESP education at MS/A and Ph.D levels at Science and Research Campus, Islamic Azad University. Human Sciences, 56, 1-28.

Nation, I. S. P., \& Macalister, J. (2010). Language curriculum design. New York: Routledge.

Rea-Dickins, P., \& Germain, K. (1993). Evaluation. Oxford: Oxford University Press.

Rezvani, R. (2013). Curriculum evaluation: Critiquing translation criticism. Paper presented at International Conference on Interdisciplinary Translation Studies. Imam Reza International University, Mashhad, Iran.

Rezvani, R., Farahzad, F. \& Vakilinejad, M. (2012). Looking at the overlooked: Students' needs and perceptions in M.A. translation quality assessment curriculum. Translation Studies, 10(38), 83-98.

Rezvani, R., \& Vakilinejad, M. (2014). An evaluation of translation quality assessment course: Voices from instructors. Procedia - Social and Behavioral Sciences, 98, 1563-1571.

Richards, J. C. (1993). Beyond the Text Book: the Role of Commerical Materials in Language Teaching. RELC Journal, 24(1), 1-14.

Richards, J. C. (2001). Curriculum development in language teaching. Cambridge: Cambridge University Press.

Stufflebeam, D. L. (2002). Fundational models for $21^{\text {st }}$ century program evaluation. In D. L. Stufflebeam, G. F. Madaus $\&$ T. Kellaghan (Eds.), Evaluation models: Viewpoints on educational and human services evaluation $\left(2^{\text {nd }}\right.$ ed., pp. 3384). USA: Kluwer Academic Publishers.

White, R. (1993). The ELT curriculum. USA: Cambridge University Press. 